\title{
FAKTOR RISIKO HIPERTENSI DITINJAU DARI KEBIASAAN MINUM KOPI (Studi Kasus di Wilayah Kerja Puskesmas Ungaran pada Bulan Januari-Februari 2012)
}

\author{
Ayu Martiani, Rosa Lelyana*) \\ Program Studi Ilmu Gizi Fakultas Kedokteran Universitas Diponegoro \\ Jl.Dr.Sutomo No.14, Semarang, Telp (024) 8453708, Email : gizifk@undip.ac.id
}

\begin{abstract}
Background: Coffee is one of the favorite beverages in the world. Coffee consumption affects hypertension has long been debated. Several studies have shown that at certain frequencies the habitual coffee consumption actually is a protective factor of hypertension. Coffee can affect blood pressure due to the presence of polyphenols, potassium, and caffeine contained in it. Polyphenols and potassium decrease blood pressure, while the caffeine increases blood pressure. The objective of this research was to know the hypertension risk factors evaluated from habitual coffee consumption.

Method: This study was an observational study with case control study design. Subjects are 94 people, 47 men in case group and 47 men in control group. The subjects were men, 45-65 years old who lived in Ungaran Public Health Service's work region, taken by consecutive sampling. Habitual coffee consumption was evaluated from coffee type, frequency, consistency of coffee, and duration of coffee drinking, which was asked directly by questionnaire. Statistical analysis used was Chi Square and done calculation of OR (Odd Ratio) to know how much risk.

Result: OR of subjects who drank $\geq 5$ cups of coffee per day ( $p=1,000$ OR=1,27, 95\% CI:0,08-21,10) lower than subjects who drank 1-2 cups of coffee per day ( $p=0,017$ OR=4,12, 95\% CI:1,22-13,39), although not statistically significant. OR of subjects drank 3-4 cups of coffee per day ( $p=1,000 ;$ OR=0,95 95\%CI:0,20-4,57) lower than abstainers, although not statistically significant. Subjects who drank 1-2 cups of coffee per day, increased the risk of hypertension 4,11 times higher ( $p=0,017$; OR=4,11 95\% CI:1,22-13,93) than abstainers.

Conclusion: Habitual coffee consumption increases the risk of incident hypertension, but depending on the frequency of daily consumption.
\end{abstract}

Key word: hypertension; habitual coffee consumption; case control

\section{ABSTRAK}

Latar Belakang: Kopi merupakan salah satu minuman favorit di dunia. Konsumsi kopi mempengaruhi hipertensi telah lama menjadi perdebatan. Beberapa penelitian menunjukkan bahwa pada frekuensi tertentu kebiasaan minum kopi justru merupakan faktor protektif hipertensi. Kopi dapat mempengaruhi tekanan darah karena adanya kandungan polifenol, kalium, dan kafein. Polifenol dan kalium bersifat menurunkan tekanan darah, sedangkan kafein bersifat meningkatkan tekanan darah. Penelitian ini bertujuan untuk mengetahui faktor risiko hipertensi ditinjau dari kebiasaan minum kopi.

Metode: Penelitian ini merupakan penelitian observasional dengan menggunakan desain kasus kontrol. Subjek penelitian sebanyak 94 orang, terdiri dari 47 kasus dan 47 kontrol. Subjek penelitian adalah pria warga wilayah kerja Puskesmas Ungaran yang berusia 45-65 tahun, diambil secara consecutive sampling. Kebiasaan minum kopi dilihat dari jenis kopi, frekuensi, kekentalan, dan lamanya minum kopi yang ditanyakan langsung dengan kuesioner. Analisis statistik yang dilakukan adalah uji Chi Square dan dilakukan perhitungan OR (Odd Ratio) untuk besarnya risiko.

Hasil: OR subjek yang minum kopi $\geq 5$ cangkir per hari kopi $(p=1,000$ OR=1,27, IK 95\%:0,08-21,10) lebih rendah dibanding subjek yang minum kopi 1-2 cangkir per hari ( $p=0,017$ OR=4,12, IK 95\%:1,22-13,39), walaupun secara statistik tidak bermakna. OR subjek minum kopi 3-4 cangkir per hari $(p=1,000 ;$ OR=0,95; IK 95\%:0,20-4,57) lebih rendah dibanding subjek yang tidak minum kopi, walaupun secara statistik tidak bermakna. Subjek yang mengkonsumsi kopi 1-2 cangkir per hari, meningkatkan risiko hipertensi 4,11 kali lebih tinggi $(p=0,017 ; 0 R=4,11$; IK95\%:1,22-13,93) dibandingkan subjek yang tidak minum kopi.

Simpulan: Kebiasaan minum kopi meningkatkan risiko kejadian hipertensi, namun tergantung dari frekuensi konsumsi harian.

Kata kunci: hipertensi; kebiasaan minum kopi; case control

${ }^{*}$ Penulis Penanggungjawab 


\section{PENDAHULUAN}

Hipertensi merupakan salah satu masalah kesehatan utama di dunia karena merupakan faktor risiko primer terjadinya penyakit jantung koroner (PJK), stroke, dan gagal jantung. ${ }^{1,2,3}$ Kira-kira jumlah orang dewasa yang menderita hipertensi pada tahun 2000 sebanyak 972 juta orang dan akan meningkat hingga $60 \%$ pada tahun 2025 menjadi sekitar 1,56 milyar orang. ${ }^{4}$ Sekitar $25 \%$ orang dewasa di Amerika memiliki tekanan darah tinggi. ${ }^{5}$ Penderita hipertensi meningkat di Jawa Tengah dari 143,82 kasus per 1.000 penduduk di tahun 2005 menjadi 166,07 kasus per 1.000 penduduk di tahun 2006. ${ }^{6}$ Hipertensi menempati peringkat kedua dari sepuluh besar penyakit yang ada di puskesmas di Semarang pada tahun 2009. ${ }^{7}$ Angka kejadian meningkat dari 18.011 pada tahun 2008 menjadi 33.065 pada tahun $2009 .^{8}$

Hipertensi dipengaruhi oleh gaya hidup dan asupan makan. Faktor-faktor risiko hipertensi antara lain usia, jenis kelamin, genetik, riwayat penyakit keluarga, kebiasaan merokok, ${ }^{1,2,3}$ asupan garam yang berlebihan, pola makan kurang optimal (kualitas dan kuantitas), aktifitas fisik yang kurang, dan berat badan yang berlebihan. ${ }^{9,10}$ Faktor asupan lain masih menjadi perdebatan adalah konsumsi kopi. ${ }^{11}$ Kopi merupakan minuman yang telah dikonsumsi sejak jaman nenek moyang dan kini kopi merupakan salah satu minuman favorit di dunia, dengan konsumsi 6,7 juta ton per tahun. ${ }^{12}$ Pengaruh kopi sekecil apapun terhadap tekanan darah akan menimbulkan dampak pada kesehatan masyarakat, karena kopi dikonsumsi secara luas di masyarakat. ${ }^{13}$ Pengaruh kopi terhadap terjadinya hipertensi saat ini masih kontroversial, selain itu hipertensi merupakan salah satu masalah kesehatan yang penting untuk diteliti. ${ }^{14} \mathrm{Hal}$ ini menjadikan masalah ini menarik untuk diteliti.

Kopi dapat mempengaruhi tekanan darah karena adanya polifenol, kalium, dan kafein yang terkandung di dalamnya. ${ }^{15}$ Polifenol dan kalium bersifat menurunkan tekanan darah. Polifenol menghambat terjadinya atherogenesis dan memperbaiki fungsi vaskuler. ${ }^{1}$ Kalium menurunkan tekanan darah sistolik dan diastolik dengan menghambat pelepasan renin sehingga terjadi peningkatan ekskresi natrium dan air. Hal tersebut menyebabkan terjadinya penurunan volume plasma, curah jantung, dan tekanan perifer sehingga tekanan darah akan turun. ${ }^{16}$ Kafein memiliki efek yang antagonis kompetitif terhadap reseptor adenosin. Adenosin merupakan neuromodulator yang mempengaruhi sejumlah fungsi pada susunan saraf pusat. ${ }^{15}$ Hal ini berdampak pada vasokonstriksi dan meningkatkan total resistensi perifer, yang akan menyebabkan tekanan darah naik.

Penelitian di USA yang dilakukan oleh Cuno Uiterwaal dkk pada tahun 2007 menunjukkan bahwa subjek yang tidak terbiasa minum kopi memiliki tekanan darah lebih rendah jika dibandingkan dengan subjek yang mengkonsumsi kopi 1-3 cangkir per hari. Pria yang mengkonsumsi kopi 3-6 cangkir per hari memiliki tekanan darah yang lebih tinggi jika dibandingkan dengan yang mengkonsumsi kopi 1-3 cangkir per hari. Pria yang mengkonsumsi kopi $>6$ cangkir per hari justru memiliki tekanan darah yang lebih rendah jika dibandingkan dengan subjek yang mengkonsumsi kopi 3-6 cangkir per hari. ${ }^{15}$

Berdasarkan latar belakang di atas, peneliti tertarik untuk meneliti faktor risiko hipertensi ditinjau dari kebiasaan minum kopi pada pria usia 45-65 tahun. Penelitian dilaksanakan di wilayah kerja Puskesmas Ungaran disebabkan jumlah kunjungan penderita hipertensi pada wilayah kerja ini terus meningkat setiap tahun dari 2123 kunjungan pada tahun 2009 menjadi 2864 pada tahun 2010. ${ }^{17}$ Selain itu, menurut Dinas Kesehatan Kabupaten Semarang, pencatatan dan pelaporan data di puskesmas ini cukup baik. Penelitian dilakukan kepada pria karena pria memiliki kecenderungan memiliki kebiasaan minum kopi yang lebih tinggi daripada wanita. Penelitian sebelumnya membuktikan bahwa pada usia di atas 44 tahun, pengaruh kopi terhadap hipertensi lebih besar jika dibanding usia dibawahnya, ${ }^{15}$ selain itu, data menunjukkan bahwa prevalensi hipertensi tinggi pada kelompok usia ini. ${ }^{17}$ Setelah melakukan penelusuran studi pustaka penelitian sejenis belum pernah dilakukan di wilayah ini.

\section{METODE}

Penelitian ini dilaksanakan di wilayah kerja Puskesmas Ungaran, Kabupaten Semarang. Pengambilan data dilakukan pada bulan JanuariFebruari 2012. Penelitian ini termasuk lingkup penelitian gizi masyarakat dan merupakan penelitian observasional dengan menggunakan desain kasus-kontrol. Populasi terjangkau adalah pria warga wilayah kerja Puskesmas Ungaran yang berusia 45-65tahun. Pengambilan subjek diawali dengan melakukan penyaringan terhadap pengunjung Puskesmas Ungaran. Subjek diperoleh dengan cara consecutive sampling yang memenuhi kriteria inklusi, yaitu berusia 45-65 tahun, IMT $<25 \mathrm{~kg} / \mathrm{m}^{2}$, dan tidak mengkonsumsi obat-obatan yang mempengaruhi tekanan darah (captopril). 
Kelompok usia ini dipilih karena penelitian sebelumnya membuktikan bahwa pada usia di atas 44 tahun, pengaruh kopi terhadap hipertensi lebih besar jika dibanding usia dibawahnya. ${ }^{15}$ Selain itu, prevalensi penderita hipertensi pada Puskesmas Ungaran lebih tinggi pada kelompok usia ini dibanding usia di bawahnya. Peneliti menentukan IMT dengan batas $<25 \mathrm{~kg} / \mathrm{m}^{2}$ karena faktor overweight dan obesitas dapat meningkatkan tekanan darah. Obesitas mendorong resistensi insulin yang merusak pembuluh darah, serta meningkatkan volume darah dan cardiac output tanpa diimbangi dengan penurunan resistensi perifer. ${ }^{1}$ Obesitas juga mengakibatkan ekskresi leptin dari lemak yang berlebihan yang mengakibatkan sistem saraf simpatik bekerja aktif sehingga tekanan darah meningkat. ${ }^{18}$ Peneliti ingin mengontrol faktor perancu lain yang mempengaruhi terjadinya hipertensi dengan melakukan restriksi. Subjek yang dipilih adalah subjek yang tidak mengkonsumsi obat hipertensi secara rutin, karena dikhawatirkan tekanan darah yang terukur merupakan pengaruh obat yang dikonsumsi subjek dan bukan tekanan darah subjek yang sebenarnya.

Indeks Massa Tubuh (IMT) diperoleh dari perhitungan berat badan (BB) dan tinggi badan (TB). Berat badan diukur dengan menggunakan timbangan digital (kapasitas $120 \mathrm{~kg}$ dengan tingkat ketelitian $0,1 \mathrm{~kg}$ ). Tinggi badan diukur dengan menggunakan mikrotoa dengan ketelitian $0,1 \mathrm{~cm}$. Subjek dikelompokkan menjadi dua kelompok yaitu kelompok kasus dan kelompok kontrol. Kelompok kontrol adalah subjek dengan tekanan darah normal (tekanan darah sistolik $<140 \mathrm{mmHg}$ dan diastolik $<90 \mathrm{mmHg}$ ). Kelompok kasus adalah subjek dengan hipertensi (tekanan darah sistolik $\geq 140 \mathrm{mmHg}$ atau diastolik $\geq 90 \mathrm{mmHg}$ ). ${ }^{1,15}$ Hipertensi dideteksi dengan minimal dua kali pengukuran, dari catatan medis di puskesmas dan pengukuran pada saat pengambilan data. Besar subjek penelitian adalah 94 orang dengan kelompok kasus sebanyak 47 orang dan kelompok kontrol sebanyak 47 orang. Besar subjek penelitian tersebut diperoleh melalui perhitungan sampel studi kasus kontrol dengan OR $2,4^{19}$, nilai kemaknaan sebesar 0,05 dan power sebesar $80 \%{ }^{20}$

Data subjek diambil dengan menggunakan kuesioner yang ditanyakan melalui wawancara secara langsung. Data yang didapat antara lain kebiasaan minum kopi, kebiasaan merokok, kebiasaan olahraga, dan data asupan $(\mathrm{Na}, \mathrm{K}$, dan serat). Kebiasaan minum kopi merupakan kebiasaan subjek tiap harinya dalam hal minum kopi, yang didefinisikan sebagai subjek yang memiliki kebiasaan minum kopi apabila secara rutin mengkonsumsi kopi minimal satu cangkir per hari. Kebiasaan minum kopi ini dilihat berdasarkan sendok kopi per cangkir yang dikonsumsi, lama minum kopi, frekuensi minum kopi (cangkir per hari, dengan air 150cc per cangkir), dan kekentalan kopi (rasio kopi, gula, dan krim dalam satuan sdt serta air dalam satuan cc). Kebiasaan merokok merupakan kebiasaan subjek mengkonsumsi rokok tiap harinya, yang didefinisikan sebagai subjek yang memiliki kebiasaan merokok apabila secara rutin mengkonsumsi rokok minimal satu batang per hari. Kebiasaan olahraga merupakan kebiasaan subjek dalam melakukan aktifias fisik (olahraga) tiap harinya, yang didefinisikan sebagai subjek yang memiliki kebiasaan olahraga apabila secara rutin melakukan olahraga minimal sekali per minggu. Data asupan merupakan asupan harian subjek yang ditanyakan dengan menggunakan Food Frequency Quessionaire (FFQ) semi kuantitatif, dengan satuan gram $(\mathrm{g})$ atau milligram (mg), yang kemudian dikategorikan menurut batas kebutuhan harian. Asupan natrium dikategorikan menjadi $\leq 1500 \mathrm{mg}$ per hari dan $>1500 \mathrm{mg}$ per hari, asupan kalium dikategorikan menjadi $\leq 4700 \mathrm{mg}$ per hari dan $>4700 \mathrm{mg}$ per hari, serta asupan serat dikategorikan menjadi $\leq 25 \mathrm{~g}$ per hari dan $>25 \mathrm{~g}$ per hari. $^{1}$

Pengolahan dan analisis data dilakukan dengan menggunakan program komputer. Dilakukan perhitungan OR (Odd Ratio) untuk mengetahui besarnya faktor risiko dari konsumsi kopi dan kafein terhadap terjadinya hipertensi dengan menggunakan uji Chi Square.

\section{HASIL PENELITIAN}

Subjek penelitian merupakan warga wilayah kerja Puskesmas Ungaran yang berjenis kelamin laki-laki dan berjumlah 47 orang pada masingmasing kelompok, yaitu kelompok subjek dengan hipertensi sebagai kelompok kasus dan kelompok subjek yang tidak hipertensi atau bertekanan darah normal sebagai kelompok kontrol. 
Tabel 1.Deskripsi Subjek Penelitian

\begin{tabular}{|c|c|c|c|}
\hline & $\begin{array}{c}\text { Kasus (\%) } \\
n=47\end{array}$ & $\begin{array}{c}\text { Kontrol (\%) } \\
\mathrm{n}=47\end{array}$ & $\begin{array}{c}\text { Jumlah (\%) } \\
\mathrm{n}=94\end{array}$ \\
\hline \multicolumn{4}{|l|}{ Kelompok umur } \\
\hline - $\quad 45-54$ tahun & $15(31,9)$ & $21(44,7)$ & $36(38,3)$ \\
\hline - $\quad 55-65$ tahun & $32(68,1)$ & $26(55,3)$ & $58(61,7)$ \\
\hline \multicolumn{4}{|l|}{ Pekerjaan } \\
\hline - PNS & $4(8,5)$ & $7(14,9)$ & $11(11,7)$ \\
\hline - $\quad$ TNI/POLRI & $0(0)$ & $2(4,3)$ & $2(2,1)$ \\
\hline - Swasta & $31(59,6)$ & $25(53,2)$ & $56(59,6)$ \\
\hline - Pensiunan & $9(19,1)$ & $9(19,1)$ & $18(19,1)$ \\
\hline - Tidak bekerja & $3(6,4)$ & $4(8,5)$ & $7(7,4)$ \\
\hline \multicolumn{4}{|l|}{ Kebiasaan minum kopi } \\
\hline - Ya & $17(36,2)$ & $9(19,1)$ & $26(27,7)$ \\
\hline - $\quad$ Tidak & $30(63,8)$ & $38(80,9)$ & $68(72,3)$ \\
\hline \multicolumn{4}{|l|}{ Kebiasaan merokok } \\
\hline - Ya & $20(48,9)$ & $23(42,6)$ & $43(45,7)$ \\
\hline - $\quad$ Tidak & $27(51,1)$ & $24(57,4)$ & $51(54,3)$ \\
\hline \multicolumn{4}{|l|}{ Kebiasaan olahraga } \\
\hline - Ya & $28(59,6)$ & $30(63,8)$ & $58(61,7)$ \\
\hline - $\quad$ Tidak & $19(40,4)$ & $17(36,2)$ & $36(38,3)$ \\
\hline \multicolumn{4}{|l|}{ Asupan $\mathrm{Na}$} \\
\hline$-\quad \leq 1500 \mathrm{mg}$ & $34(70,2)$ & $33(72,3)$ & $67(71,3)$ \\
\hline$-\quad>1500 \mathrm{mg}$ & $13(29,8)$ & $14(27,7)$ & $27(28,7)$ \\
\hline \multicolumn{4}{|l|}{ Asupan K } \\
\hline - $\quad<4700 \mathrm{mg}$ & 47 (100) & $47(100)$ & $94(100)$ \\
\hline$-\quad \geq 4700 \mathrm{mg}$ & $0(0)$ & $0(0)$ & $0(0)$ \\
\hline \multicolumn{4}{|l|}{ Asupan serat } \\
\hline$-\quad \leq 25$ gram & $47(100)$ & $47(100)$ & $94(100)$ \\
\hline$>25$ gram & $0(0)$ & $0(0)$ & $0(0)$ \\
\hline
\end{tabular}

Tabel 1. menunjukkan karakteristik subjek penelitian, yaitu sebagian besar subjek penelitian berusia antara 55-65 tahun (61,7\%). Pekerjaan sebagian besar subjek penelitian bekerja pada swasta $(59,6 \%)$. Kebiasaan merokok lebih tinggi pada kelompok kontrol $(48,9 \%)$ dibanding kelompok kasus $(42,6 \%)$. Kebiasaan berolahraga juga lebih tinggi pada kelompok kontrol $(63,8 \%)$ dibanding kelompok kasus (58,7\%). Asupan natrium sebagian subjek cukup $(71,3 \%)$ sedangkan asupan kalium, dan serat subjek penelitian memiliki tingkat asupan yang kurang.

Tabel 2. Kebiasaan Minum Kopi dan Hipertensi Dilihat dari Frekuensi, Jenis Kopi, Jumlah Kopi, Lama Minum Kopi, dan Kekentalan Kopi

\begin{tabular}{lccccc}
\hline \multicolumn{1}{c}{ Variabel } & $\begin{array}{c}\text { Kasus (\%) } \\
\mathrm{n}=47\end{array}$ & $\begin{array}{c}\text { Kontrol (\%) } \\
\mathrm{n}=47\end{array}$ & $\begin{array}{c}\text { Rasio } \\
\text { Odds }\end{array}$ & IK 95\% & $p$ \\
\hline $\begin{array}{l}\text { Frekuensi minum kopi } \\
0 \text { cangkir per hari }\end{array}$ & $30(63,8)$ & $\begin{array}{c}38(80,9) \\
4(8,5)\end{array}$ & $\begin{array}{c}1,00 \\
4,12\end{array}$ & $1,22-13,93^{*}$ & 0,017 \\
$\begin{array}{l}1-2 \text { cangkir per } \\
\text { hari }\end{array}$ & $13(27,7)$ & & & & \\
$\begin{array}{l}3-4 \text { cangkir per } \\
\text { hari }\end{array}$ & $3(6,4)$ & $4(8,5)$ & 0,95 & $0,20-4,57$ & 1,000 \\
$\begin{array}{l}\geq 5 \text { cangkir per hari } \\
\text { Jenis kopi }\end{array}$ & $1(2,1)$ & $1(2,1)$ & 1,27 & $0,08-21,10$ & 1,000 \\
$\begin{array}{l}\text { Tidak minum kopi } \\
\text { Kopi murni }\end{array}$ & $30(63,8)$ & $38(80,9)$ & 1,00 & & \\
Kopi tidak murni & $14(29,8)$ & $8(17,0)$ & 2,22 & $0,82-6,98$ & 0,111 \\
& $3(6,4)$ & $1(2,1)$ & 3,80 & $0,38-38,41$ & 0,327 \\
\hline
\end{tabular}




\begin{tabular}{lccccc} 
Takaran kopi & \multicolumn{3}{l}{} & & \\
0 sdt & $30(63,8)$ & $38(80,9)$ & 1,00 & & \\
1 sdt & $13(27,7)$ & $6(12,8)$ & 2,74 & $0,93-8,08$ & 0,061 \\
2 sdt & $4(8,5)$ & $3(6,4)$ & 1,69 & $0,35-8,13$ & 0,695 \\
Lama minum kopi & & & & & \\
0 tahun & $30(63,8)$ & $38(80,9)$ & 1,00 & & \\
$<1$ tahun & $0(0)$ & $1(2,1)$ & 1,79 & $1,45-2,21$ & 1,000 \\
$1-2$ tahun & $0(0)$ & $1(2,1)$ & 1,79 & $1,45-2,21$ & 1,000 \\
$3-5$ tahun & $3(6,4)$ & $1(2,1)$ & 3,80 & $0,38-38,41$ & 0,327 \\
6-10 tahun & $6(12,8)$ & $1(2,1)$ & 7,60 & $0,87-66,59$ & 0,050 \\
$11-20$ tahun & $2(4,3)$ & $0(0)$ & 2,27 & $1,74-2,96$ & 0,205 \\
$>20$ tahun & $6(12,8)$ & $5(10,6)$ & 1,52 & $0,42-5,47$ & 0,519 \\
Kekentalan kopi (rasio kopi(sendok):gula(sendok):krim(sendok):air(cc) & \\
$1: 1: 0: 150$ & $3(6,4)$ & $1(2,1)$ & 3,80 & $0,38-38,41$ & 0,327 \\
$1: 2: 0: 150$ & $6(12,8)$ & $4(8,5)$ & 1,90 & $0,49-7,35$ & 0,500 \\
$1: 3: 0: 150$ & $1(2,1)$ & $0(0)$ & 2,27 & $1,74-2,96$ & 0,449 \\
$2: 2: 0: 150$ & $3(6,4)$ & $3(6,4)$ & 1,27 & $0,24-6,73$ & 1,000 \\
$2: 3: 0: 150$ & $1(2,1)$ & $0(0)$ & 2,27 & $1,74-2,96$ & 0,449 \\
$1: 1: 1: 150$ & $2(4,3)$ & $0(0)$ & 2,27 & $1,74-2,96$ & 0,205 \\
$1: 2: 1: 150$ & $1(2,1)$ & $1(2,1)$ & 1,27 & $0,08-21,10$ & 1,000 \\
\hline
\end{tabular}

*secara statistik bermakna $(p<0,05)$

Tabel 2 menunjukkan kebiasaan minum kopi subjek penelitian. Subjek yang memiliki kebiasaan minum kopi 1-2 cangkir per hari meningkatkan risiko hipertensi 4,12 kali lebih tinggi dibanding subjek yang tidak memiliki kebiasaan minum kopi $p=0,017 \quad(\mathrm{OR}=4,12, \quad$ IK $\quad 95 \% \quad 1,22-13,39)$. Berdasarkan jenis kopi yang dikonsumsi, pada konsumsi kopi tidak murni menghasilkan nilai OR yang lebih tinggi dibanding kopi murni, dengan $p=0,111(\mathrm{OR}=2,22$, IK 95\% 0,82-6,98) untuk kopi murni dan $p=0,327(\mathrm{OR}=3,80$, IK 95\% 0,38-38,41) untuk kopi tidak murni. Takaran kopi 1 sdt maupun 2 sdt per cangkir memiliki nilai OR yang tinggi yaitu 2,74 untuk 1 sdt $(p=0,061 \mathrm{OR}=2,74$, IK 95\% 0,93-8,08) dan 1,69 untuk 2 sdt kopi $(p=0,695 \quad \mathrm{OR}=1,69, \quad$ IK $\quad 95 \% \quad 0,35-8,13)$. Berdasarkan lama subjek minum kopi, OR tertinggi pada 6-10 tahun $(p=0,050 \mathrm{OR}=7,60$, IK 95\% 0,87-66,59). Hasil perhitungan OR berdasarkan lama minum kopi ini tidak ada yang signifikan secara statistik. Berdasarkan kekentalan kopi yang dikonsumsi, OR tertinggi adalah pada takaran kopi $1 \mathrm{sdt}$ dengan gula $1 \mathrm{sdm}$ dan air $150 \mathrm{cc}$ tanpa menggunakan krim $(p=0,327 \mathrm{OR}=3,80, \mathrm{IK}$ 95\% 0,38-38,41). Hasil perhitungan OR kebiasaan minum kopi berdasarkan kekentalan kopi yang dikonsumsi ini tidak ada yang menunjukkan hubungan yang signifikan berdasarkan statistik.

\section{PEMBAHASAN}

Hasil penelitian menunjukkan bahwa subjek penelitian adalah warga wilayah kerja Puskesmas
Ungaran berjenis kelamin laki-laki berusia 45-65 tahun. Kelompok umur terbanyak adalah usia 5565 tahun. Risiko kenaikan tekanan darah meningkat seiring dengan bertambahnya usia. $^{2}$ Peningkatan usia seiring dengan proses patogenesis hipertensi karena pada proses penuaan terjadi tanda-tanda aterosklerosis yang menunjang peningkatan perifer total dan selanjutnya tahanan pembuluh darah ini meningkatkan afterload bagi fungsi jantung, sehingga jantung harus bekerja lebih berat yang mengakibatkan terjadinya hipertensi. ${ }^{21}$ Pekerjaan yang paling banyak pada kedua kelompok adalah swasta. Subjek yang bekerja swasta meliputi buruh pabrik, buruh tani, pekerja toko, supir, dan tukang bengkel. Subjek yang memiliki pekerjaan swasta lebih banyak pada kelompok kasus dibanding kelompok kontrol. Pekerjaan berhubungan dengan tingkat stressor sehingga dapat memicu hipertensi. Hal ini disebabkan oleh stimulasi sistem saraf untuk memproduksi hormon vasokonstriksi yang dapat meningkatkan tekanan darah. ${ }^{22}$

Berdasarkan frekuensinya, subjek yang minum kopi 1-2 cangkir per hari memiliki OR tertinggi yaitu 4,12 dan secara statistik signifikan $(p<0,05)$. Hal ini membuktikan bahwa subjek yang memiliki kebiasaan minum kopi 1-2 cangkir per hari meningkatkan risiko hipertensi sebanyak 4,12 kali lebih tinggi dibanding subjek yang tidak memiliki kebiasaan minum kopi. Hal ini sesuai dengan penelitian Michael J. Klag dkk yang menunjukkan bahwa risiko hipertensi konsumsi 
kopi 1-2 cangkir per hari lebih tinggi jika dibandingkan dengan konsumsi kopi 0 cangkir per hari. ${ }^{23}$ Kandungan terbesar dalam kopi, yaitu kafein, memiliki efek terhadap tekanan darah secara akut, terutama pada penderita hipertensi. ${ }^{19}$ Peningkatan tekanan darah ini terjadi melalui mekanisme biologi antara lain kafein mengikat reseptor adenosin, mengaktifasi sistem saraf simpatik dengan meningkatkan konsentrasi cathecolamines dalam plasma, dan menstimulasi kelenjar adrenalin serta meningkatkan produksi kortisol. ${ }^{19}$ Hal ini berdampak pada vasokonstriksi dan meningkatkan total resistensi perifer, yang akan menyebabkan tekanan darah naik. ${ }^{15}$ Kandungan kafein pada kopi berbeda-beda tergantung pada jenis kopi, asal kopi, iklim daerah kopi dibudidayakan, dan proses pengolahan kopi. ${ }^{24}$ Kopi yang diproduksi dan diperdagangkan di Indonesia sebagian besar adalah kopi robusta. Jenis kopi ini memiliki kandungan kafein (2-3\%) yang lebih tinggi dibandingkan kopi arabika $(1-1.3 \%){ }^{25}$ Kandungan kafein tiap cangkir kopi adalah 60,4$80,1 \mathrm{mg}{ }^{26}$

Hasil penelitian menunjukkan bahwa subjek yang memiliki kebiasaan minum kopi $>3$ cangkir per hari dapat mentoleransi efek kafein pada kopi, sehingga tidak berefek meningkatkan tekanan darah. Tubuh memiliki regulasi hormon kompleks yang bertugas menjaga tekanan darah yang dapat menyebabkan toleransi tubuh terhadap paparan kafein pada kopi secara humoral dan hemodinamik, ketika paparan kafein itu terjadi secara terus menerus. ${ }^{19}$ Selain memiliki kandungan yang bersifat meningkatkan tekanan darah, kopi mengandung substansi yang bersifat menurunkan tekanan darah yaitu polifenol dan kalium. Kopi yang dikonsumsi subjek merupakan kopi instan. Kopi instan mengandung serat larut air yang tinggi dan dihubungkan dengan kandungan polifenol (antioksidan). ${ }^{27}$ Kandungan kalium dalam kopi diketahui tinggi. ${ }^{15}$ Polifenol menghambat terjadinya atherogenesis dan memperbaiki fungsi vaskuler. ${ }^{1}$ Kalium menurunkan tekanan darah sistolik dan diastolik dengan menghambat pelepasan renin sehingga terjadi peningkatan ekskresi natrium dan air. Hal tersebut menyebabkan terjadinya penurunan volume plasma, curah jantung, dan tekanan perifer sehingga tekanan darah akan turun. ${ }^{16}$ Polifenol dan kalium dapat menyeimbangkan efek kafein. Konsumsi kopi pada dosis tertentu, cenderung menurunkan tekanan darah. Hal ini disebabkan oleh kandungan kalium pada kopi yang tinggi. ${ }^{15}$ Penelitian meta analisis telah dilakukan untuk membandingkan perubahan tekanan darah antara subjek yang diberi tablet kafein dan subjek yang diberi kafein dalam kopi. Penelitian ini menghasilkan peningkatan tekanan darah pada subjek yang diberi tablet kafein lebih tinggi dibandingkan subjek yang diberi kafein melalui kopi. ${ }^{13} \mathrm{Hal}$ ini memungkinkan penurunan tekanan darah yang disebabkan oleh kalium dan polifenol pada kopi mempengaruhi efek kafein yang terkandung di dalamnya. Penelitian sebelumnya yang dilakukan oleh Cuno dkk menunjukkan pada peminum kopi berat ( $>6$ cangkir per hari) justru risiko terhadap hipertensi lebih rendah jika dibandingkan dengan peminum kopi ringan $(>0-3$ cangkir per hari). ${ }^{15}$ Hasil peneltian tersebut sesuai dengan penelitian ini, di mana hasil perhitungan OR tidak selalu meningkat, akan tetapi turun pada konsumsi 3-4 cangkir per hari. Hasil perhitungan statistika 3-4 cangkir kopi menunjukkan $\mathrm{OR}=0,95$ dan pada $\geq 5$ cangkir per hari menunjukkan $\mathrm{OR}=1,27$ walaupun hasil perhitungan ini tidak signifikan. Hal ini disebabkan oleh jumlah sampel yang kurang banyak. Sebagian besar subjek yang memiliki tekanan darah tinggi, mengkonsumsi 1-2 cangkir per hari.

Jenis kopi yang didapatkan pada penelitian ini ada dua, yaitu kopi murni dan kopi tidak murni. Kopi murni adalah kopi hitam yang diseduh tanpa menggunakan campuran susu atau krim. Hasil perhitungan statistika menghasilkan nilai OR 2,22 untuk konsumsi kopi murni dan 3,80 untuk konsumsi kopi tidak murni yang secara statistika tidak bermakna.

Tiap cangkir kopi yang dikonsumsi subjek mengandung 1-2 sdt kopi hitam. Takaran kopi yang digunakan oleh subjek penelitian ini sebagian besar menggunakan 1 sdt. Takaran ini berhubungan dengan kekentalan kopi. Hasil penelitian ini meunjukkan kekentalan kopi tidak bermakna sebagai faktor risiko hipertensi. Semakin kental kopi, maka kandungan kefein semakin tinggi. Kafein memiliki sifat diuretik pada ginjal sehingga meningkatkan ekskresi urin ${ }^{28}$. Sifat diuretik ini mampu menurunkan tekanan darah dengan meningkatkan ekskresi air dan natrium. ${ }^{1} \mathrm{Di}$ sisi lain konsumsi kopi berdampak pada terjadinya vasokonstriksi pembuluh darah. ${ }^{15}$ Oleh karena itu, dengan kebiasaan minum kopi maka tubuh mampu mentoleransi dampak kafein.

Kopi tidak murni yang dikonsumsi subjek adalah kopi instan yang merupakan campuran kopi, krimer, dan gula. Tiap $1 \mathrm{sdm}$ krimer mengandung $10 \mathrm{mg}$ kalori, $2 \mathrm{gr}$ karbohidrat, $500 \mathrm{mg}$ gula, $500 \mathrm{mg}$ lemak, dan $5 \mathrm{mg}$ natrium. ${ }^{29}$ Rendahnya kandungan 
gizi yang terdapat dalam krimer ini tidak banyak mempengaruhi tekanan darah, walaupun di dalamnya terkandung natrium yang diketahui dapat menaikkan tekanan darah jika dikonsumsi dalam jumlah yang berlebihan. Setelah dilakukan uji statistik, tidak didapatkan hasil yang bermakna, baik untuk takaran kopi 1 sdt maupun 2 sdt.

Lama minum kopi tidak berhubungan dengan peningkatan risiko hipertensi. Sebagian besar subjek memiliki kebiasaan minum kopi selama lebih dari 20 tahun. Perhitungan OR tertinggi pada peminum kopi 6-10 tahun. Peneliti menganalisis lama minum kopi yang dihubungkan dengan faktor risiko hipertensi karena individu yang memiliki kebiasaan minum kopi, semakin lama akan dapat mentolerir kafein yang terdapat dalam kopi. ${ }^{19}$ Hal ini disebabkan tubuh memiliki mekanisme hormonal yang menyebabkan toleransi tubuh terhadap paparan kafein, ketika paparan ini terjadi secara terus menerus. ${ }^{19}$ Peneliti ingin mengetahui seberapa lama individu dapat mentoleransi kafein kopi. Hasil yang didapatkan tidak signifikan, karena kurangnya jumlah sampel, sehingga hasil tidak dapat disimpulkan.

Hasil perhitungan OR sebagian besar tidak bermakna secara statistik. Dilihat dari deskripsi subjek penelitian, pada kelompok kasus, yaitu kelompok subjek yang menderita hipertensi, subjek yang tidak memilliki kebiasaan minum kopi lebih banyak dibanding subjek yang memiliki kebiasaan minum kopi. Hal ini menunjukkan bahwa hipertensi tidak disebabkan oleh faktor kebiasaan minum kopi saja. Kebiasaan olahraga, kebiasaan merokok dan kebiasaan makan subjek (asupan $\mathrm{Na}$, $\mathrm{K}$, serat) juga berperan terhadap kejadian hipertensi. Olahraga memperbaiki fungsi endotelium. Lapisan endotel pada dinding pembuluh darah berfungsi menjaga kenormalan denyut nadi dan mengatur elastisitas pembuluh darah. Olahraga juga dapat meningkatkan panjang dan diameter pembuluh darah. Orang yang terbiasa berolahraga memiliki diameter arteri yang lebih besar dibanding orang yang tidak terbiasa berolahraga. ${ }^{30}$ Merokok dapat meningkatkan risiko hipertensi. Merokok mampu merusak jantung secara langsung dengan memicu vasokonstriksi dan mempercepat detak jantung yang akan menyebabkan jantung bekerja keras dan meningkatkan tekanan darah. ${ }^{31}$ Nikotin dalam rokok dapat mengikat oksigen dalam jantung dan merusak platelet, serta membentuk gumpalan darah. Nikotin juga dapat merusak pembuluh darah. Rusaknya pembuluh darah ini merupakan langkah pertama aterosklerosis. Apabila individu berhenti merokok maka risiko penyakit jantung koroner dapat menurun. ${ }^{1}$ Natrium yang berlebih akan meningkatkan konsentrasi natrium di dalam cairan ekstraseluler, yang menyebabkan peningkatan tekanan darah. ${ }^{16}$ Kalium bekerja berkebalikan dengan natrium. Kalium menurunkan tekanan darah sistolik dan diastolik dengan menghambat pelepasan renin sehingga terjadi peningkatan ekskresi natrium dan air. Hal tersebut menyebabkan terjadinya penurunan volume plasma, curah jantung, dan tekanan perifer sehingga tekanan darah akan turun. ${ }^{16}$ Kebutuhan serat harian adalah $25 \mathrm{gr} / \mathrm{hari}^{2}{ }^{2}$ Serat larut air akan mempengaruhi tekanan darah dengan mencegah penyerapan asam empedu, kolesterol dan lemak sehingga tekanan perifer akan berkurang. Hal ini menyebabkan menurunnya tekanan darah. ${ }^{1,2}$ Hasil penelitian menunjukkan bahwa sebagian besar subjek penelitian memiliki tingkat asupan natrium, kalium, dan serat yang rendah.

Kelemahan penelitian ini salah satunya adalah tidak meneliti faktor genetik. Faktor genetik mempengaruhi kepekaan tubuh dalam merespon kopi yang berdampak pada tekanan darah. ${ }^{19}$ Asupan kafein dapat menjadi faktor risiko pada individu yang secara genetik memiliki kemampuan metabolisme kafein dengan lambat. ${ }^{32}$ Penggunaan metode FFQ pada penelitian ini menyebabkan unsur subjektivitas tidak dapat terlepas dari penelitian. Metode ini memungkinkan terjadinya bias karena sangat tergantung dengan daya ingat subjek. Hal ini juga dapat menyebabkan flat slope syndrome pada subjek saat wawancara dilakukan. Untuk penelitian selanjutnya perlu dilakukan penambahan jumlah sampel agar hasil penelitian bisa mewakili masyarakat yang lebih luas dan dapat digeneralisasikan.

\section{SIMPULAN}

Kebiasaan minum kopi meningkatkan risiko kejadian hipertensi, namun tergantung dari frekuensi konsumsi harian.

\section{DAFTAR PUSTAKA}

1. Krummel DA. Medical Nutrition Therapy for Cardiovascular Disease: Mahan K, Escott-Stump S. Krause's food, nutrition and diet therapy. 11th edition. Philadelphia: Saunders; 2004. p.151, p.866, p.850, p.868, p.871, p.872, p.873.

2. Whitney E, Rolfes SR. Hypertension. Dalam : Understanding Nutrition 11th edition. Belmont : Wadsworth; 2008. p.633-634, p632, p634-635, p155, p.400, p.503, p.505. 
3. Idham Idris. Hypertension in the Elderly. Jurnal Kardiologi Indonesia. Jakarta: Perhimpunan Dokter Spesialis Kardiovaskuler Indonesia; 2002. p.44.

4. Kearny PM, Whelton M, Reynolds K, et al. Global Burden of Hypertension: Analysis of Worldwide Data. Lancet, 365:217-23

5. Coulston AM, Rock CL, Monsen ER, King Janet(Ed.). Nutrition in the Prevention and Treatment of Disease. USA: Academic Press; 2001. p.303.

6. Dinas Kesehatan Provinsi Jawa Tengah. Profil Kesehatan Provinsi Jawa Tengah Tahun 2006. [serial online] 2006 [dikutip pada 28 Desember 2011]. Tersedia dari: URL HYPERLINK: http://depkes.go.id

7. Dinas Kesehatan Kota Semarang. Profil Kesehatan Kota Semarang 2009. [serial online] 2009 [dikutip pada 29 Desember 2011]. Tersedia dari: URL HYPERLINK: http://www.dinkeskotasemarang.go.id

8. Dinas Kesehatan Kota Semarang. Profil Kesehatan Kota Semarang 2008. [serial online] 2009 [dikutip pada 29 Desember 2011]. Tersedia dari: URL HYPERLINK: http://www.dinkeskotasemarang.go.id

9. Jones DW. Dietary Sodium and Blood Pressure. Hypertension 2004;43:932-5

10. Geleijinse JM, Kok FJ, Grobbee DE. Impact of Dietary and Lifestyle Factors on the Prevalence of Hypertension in Western Population. Eur J Public Health 2004; 14:235-9.

11. Hamer M. Coffee and Health: Explaining Conflicting Results in Hypertension. Journal of Human Hypertension 2006; 20:909-912.

12. Baylin A, Hernandez-Diaz S, Kabagambe EK, SIles $\mathrm{X}$, Campos H. Transient Exposure to Coffee as a Trigger of a First Nonfatal Myocardial Infarction. Epidemiology 2006;17:506-11.

13. Noordzij M, Uiterwaal CSPM, Arends LR, Kok FJ, Grobbee DE, Geleijnse JM. Blood Pressure Response to Chronic Intake of Coffee and Caffeine: a Meta-Analysis of Randomized Controlled Trials. Journal of Hypertension 2005; 23:921-28.

14. Sica V, Bellinghieri G, Kopple JD. The Effect of Nutrition on Blood Pressure. Annu Rev Nutr 2010;30:365-401.

15. Uiterwaal Cuno, Verschuren Monique, Bueno-deMesquita Bas, Ocké Marga, Geleijnse J.M, Boshuizen H.C, et al. Coffee Intake and Incidence of Hypertension. Am J Clin Nutr 2007; 85: 718-23

16. Adrogue HJ, Madias NE. Sodium and Potassium in the Pathogenesis of Hypertension. N Engl J Med 2007; 356:1966-1978

17. Dinas Kesehatan Kabupaten Semarang. Profil Kesehatan Kabupaten Semarang Tahun 2010. Semarang: Dinas Kesehatan Kabupaten Semarang; 2010.
18. Tesfaye F, Nawi NG, Minh HV, Byass P, Berhane Y, Bonita R, Wall S. Association Between Body Mass Index and Blood Pressure Across Three Populations in Africa and Asia. J Hum Hypertens 2007; 1:28-37.

19. Zhang Zhenzhen, Hu Gang, Caballero Benjamin, Appel Lawrence, Chen Liwei. Habitual Coffee Consumption and Risk of Hypertension: A Systematic Review and Meta-Analysis of Prospective Observational Studies. Am J Clin Nutr 2011.

20. Sastroasmoro Sudigdo, Ismael Sofyan. Dasar Dasar Metodologi Penelitian Klinis. Jakarta : Binarupa Aksara;1995. Hal 206 - 212.

21. Masud Ibnu. Dasar-Dasar Fisiologi Kardiovaskuler. Jakarta: penerbit Buku Kedokteran EGC; 1996. p.110, p.132, p111,p133.

22. Rustanti ID. Studi Diskriptif Tentang Stres Sebagai Pencetus Hipertensi. [skripsi]. Malang: Fakultas Psikologi Universitas Muhammadiyah Malang. 2003.

23. Klag MJ, Wang NY, Meoni LA, Brancati FL, Cooper LA, Liang KY, et al. Coffee Intake and Risk of Hypertension. Arch Intern Med 2002;162:657662.

24. Dieter Belitz, Grosch Werner, Schieberle Peter. Food Chemistry. Jerman: Spinger; 2009. p.940, p.947

25. Siswoputranto PS.. Kopi Internasional dan Indonesia. Yogyakarta: Penerbit Kanisius; 1993. p.35

26. Kenneth PC. Caffeine and Health Research. New York: Nova Science Publishers, Inc.; 2009. p.162

27. Diaz-Rubio ME, Saura-Calixto F. Dietary Fiber in Brewed Coffee. J Agric Food Chem, 2007; 55:19992003

28. Wanyika H.N , Gatebe EG, Gitu LM, Ngumba EK, and Maritim CW. Determination of Caffeine Content of Tea And Instant Coffee Brands Found in the Kenyan Market. African Journal of Food Science 2010; 4(6):353-358.

29. Third Age Media. Food and Nutrition Information and Facts. [serial online] 2012 [dikutip pada 25 September 2012]. Tersedia dari: URL HYPERLINK http://www.thirdage.com/

30. Baster Tom, Baster-Brook Christine. Exercise and Hypertension. Australia: Australian Family Physician; 2005.

31. Okubo Y, Miyamoto T, Suwazono Y, Kobayashi E and Nogawa K. An Association Between Smoking Habits and Blood Pressure in Normotensive Japanese Men. Jepang. Drug Alcohol Depend 2004; 73(2):167-74.

32. Cornelis MC, El-Sohemy A, Kabagambe EK, Campos H. Coffee, CYP1A2 Genotype, and Risk of Myocardial Infarction. JAMA 2006; 295: 1135-1141 